\title{
GOVERNANCE ISSUES IN PAKISTAN AND THEIR IMPACT ON INCOME INEQUALITY
}

\author{
Athar Iqbal1 \\ Assistant Professor, Iqra University \\ Dr. Ayub Mehar2 \\ Professor, Iqra University
}

\begin{abstract}
Purpose- The purpose of this paper is to investigate the relation between governance of a country and its impact on income inequality. The World Bank, Economic Freedom Network, Fraser Institute and World Economic Forum have been defining and measuring the governance indicators.
\end{abstract}

Methodology/Sample - This study takes six governance indicators score from-WWGI for the year 2000 and 156 counties data to calculate correlation between wealth Gini and governance indicators. The statistical analysis is comprises of OLS estimation and Correlation analysis.

Findings - We found significant negative relation between governance indicators and wealth inequality, income inequality. Bad governance has deep impacts on economy of Pakistan. Excessive debt, high fiscal deficit, high inflation, low tax to GDP ratio, high trade deficit, lack of adequate capital formation and severe energy crisis are some of the economic challenges faces by Pakistan from decades.

Practical Implications - This study suggests that improvement in governance is not a single day task, it cannot be achieved at once and it is not related to any department or institution. It's a process that will establish equality, effective management of economic resources.

Keywords : governance, income inequality, fiscal deficit

\section{Jel Classification: D63,D60, G38}

\footnotetext{
* The material presented by the author does not necessarily portray the viewpoint of the editors and the management of the Institute of Business \& Technology (IBT)

* Athar Iqbal : : athar@iqra.edu.pk

* Dr. Ayub Mehar : ayubmehar@yahoo.com

(C) IBTJBS is published by the Institute of Business and Technology (IBT).

Main Ibrahim Hydri Road, Korangi Creek, Karachi-75190, Pakistan.
} 


\section{INTRODUCTION}

\subsection{Overview}

Human Development in South Asia (1999) observed that South Asia is a region which is divided among rich and very poor as richest one-fifth population earn approximately 40 percent of the income and poorest one-fifth earn less than 10 percent of the income, so there is a wide gap between rich and poor in South Asia. Rich and poor are divided apart; on the other hand some of this region emerged as most poorly governed regions in the world. A region where 515 million people are struggling for their survival and future of 395 million illiterate adults are at stake. These illiterate people have no source of regular earning and no training to get jobs.

With the help of economic data of South Asia it can be said that by only growth of GDP of any country, all economic and social problems will not be solved. In South Asia we have problems of governance and this crisis of governance in South Asia can halt economic and social progress of this region. South Asia has extreme income inequality where richest 10 percent is six times richer than the poorest 10 percent; this shows lack of governance in economic system where equitable distribution is almost impossible (Human Development in South Asia, 1999).

Human Development in South Asia (1999) observed that South Asia has many governance issues like in this region income tax is only paid by one percent of the population and share of direct taxes is only 29 percent of the total revenue generated by taxes. Human Development in South Asia (1999) presented and compared two indexes, Human Poverty Index (HPI) which is prepared by UNDP, Poverty of Opportunity Index (POPI) which is prepared by Dr. Mahbub ul Haq with $\$ 1$ a day as defined by World Bank for poverty incidence and showed that other than India all other countries in South Asia is more poor when analyzed on the basis of HPI and POPI. Pakistan's HPI and POPI is four times higher than income poverty as defined by World Bank which is clear indication of poor governance in Pakistan where whatever income generated by country couldn't be transferred to people on equitable basis.

Pakistan's performance in sixty five years after independence is not very disappointing. Pakistan's poverty ratio has declined and economy shifted to more diversified production structure from agrarian economy. Integration with the world economy has been fairly good, and liberalization and deregulation of the economy have begun to take root. But potential for growth and development is far more that what realized by Pakistan. Human development indicators computed by United Nations Development Program (UNDP) of Pakistan is far behind other countries of Asia and rest of the world. Overall literacy rates, life expectancy, infant mortality are much below than neighboring countries as well as from those countries who are around same per capita income level. Fiscal and monetary policies have been lax, and the gains achieved by establishing sound institutions in the earlier years are being gradually eroded. The physical infrastructure has not kept pace with the speed and level of economic activity. Technological and scientific progress has been limited despite possession of nuclear technology. 


\subsection{Current Situation}

Pakistan economy is facing various problems. These problems are of multiple natures. Some of the issues are given below which may help to understand its dynamics. The News (2012) reported that Pakistan as per Global Competitiveness Report 2012-2013 has been ranked among the bottom 20 out of 144 economies around the world. World Bank's doing business report kept Pakistan at 128th position out of 189 countries and considered it a tough place to do business. According to Failed State Index (renamed Fragile States Index) ranking, Pakistan stands at number 13. Pakistan falls under the 'high alert' category. Pakistan ranked 74 out of the 82 countries as per The Economist Intelligence Unit (EIU) released the business environment ranking for 2014.As per survey of Transparency International 2012, Pakistan ranked at 139 on the scale of 1175.As per Economic Freedom Report rating, Pakistan stands at 111 out of 144 countries ranked. According to HDI ranking by UNDP in year 2012, Pakistan ranked at 146 out of 187 countries. Pakistan falls under the 'low human development' group.KOF Index of Globalization which measures economic, social and political dimensions of globalization ranked Pakistan at 108 out of 166 countries in 2012.

\section{LITERATURE REVIEW}

The word governance is not new, as Human Development in South Asia (1999) observed that much has been discussed and written about governance, and specifically about good governance by academics and international policy makers. It is argued that governance took its importance after collapse of communism when transitional economies found it difficult to cope up with the emerging market economy. Transitional economies faceed lack of proper institutions, unfulfilled contracts, poor protection of rights, poor insurance mechanism and poor civil society. The objective of governance in any society should be social development as well as economic growth and prosperity.

Governance is studied and advised by the World Bank as the way in which power is applied in the administration of a country economic and social resources. The World Bank pointed out three specific areas of governance, first is structure of political government, second how authority is applied to manage country's resources for social and economic development and third is, government capacity to design, formulate, and implement policies and discharge functions.

Kaufmann, Kraay, and Zoido-Lobatón (1999) developed six governance indicators called Worldwide Governance Indicators (WGI) namely Voice and Accountability,Political Instability and Violence, Government Effectiveness, Regulatory Burden, Rule of Law and Graft.

Kaufmann, Kraay, and Zoido-Lobatón (1999) presented examples of Ukraine and Russia where because of weak governance, in terms of lack of property rights, and ineffective rule of law, living standards are at decline. Kaufmann et al. (1999); Rajkumar and Swaroop (2008) pointed out that good governance has positive impact on growth and development while weak governance slows economic growth and development. 
Hyden and Court (2002) argued that political developemnt is a prerequisite for growth and development of any society. Keefer (2004) observed that intially governance was considered to understand economic performance of developing countries with emphasis on certain characteristics but later performance of bureaucracy, property rights, credibility of government policies and decision making, and institutional characteristics are also considered.

Corruption is always with us as argued by (Aidt 2003). There is growing literature on corruption and governance in which Transparency International, World Bank, UNDP are more popular. Kaufmann, Hellman, Jones, and Schankerman (2000) observed that corruption is basically a governance problem.

Mauro (1995) explored channels through which corruption impacts on economic growth and finds negative association between corruption and investment and growth. According to estimate a one standard deviation improvement in the corruption index will increase investment rate by $2.9 \%$ of GDP. Brunetti and Weder (1998); Shen and Williamson (2005) further confirmed Mauro (1995) findings.

\subsection{Income Inequality and Governance}

It is argued that income inequality is harmful for growth as well as political instability is also negatively associated with growth and investment (Barro, 1991; Alesina, Özler, Roubini, \& Swagel, 1996; Venieris \& Gupta, 1986; Mauro, 1995; Alesina \& Perotti, 1996; Ortiz \& Cummins, 2011). Benabou (1996) argued that the more unequal country in terms of wealth and income grew more slowly.

Akram, Wajid, Mahmood, and Sarwar (2011) argued that there is a relationship among bad governance, income inequality and poverty level.De Kruijk, Van Leeuwen, and Kemal (1985) examined inequality and poverty in Pakistan during 1970s. It is found that poverty decreases by 50 percent and income inequality rises in same period. Another work in similar area by (De Kruijk \& Kemal,1987) observed that in Pakistan with the information available it is clear that poverty declines while inequality rises.

Adams and Alderman (1992) explored sources of income inequality in rural Pakistan during 1987 to 1989 and found income inequality increases during the survey period from 0.384 to 0.417 . Alesina and Rodrik (1994) observed that in any country when distribution of resources are more unequal, economic growth and prosperity of that country will be lower than the society where distribution of resources are not much unequal.

Glaeser, Scheinkman, and Shleifer (2003) observed and presented model that inequality is badfor_growth but only in those countries where rule of law is poor consequently political institutions are weak and institutional breakdown is common. Kemal (2006) discussed that objective of economic growth and development is to change the living standard of people living in society, only growth is not enough, equitable distribution is also required.

Akhtar (2008); Khandker (1973) showed serious doubt on various reports and data 
presented in Pakistan about regional inequality. Akhtar (2008) took data from 199899 to 2004-05 and found that poor percentage in Pakistan reduced from 31.1\% in 199899 to $23.9 \%$ in 2004-05. Similar trend of decline reported in urban and rural headcount. On the other hand 2005-06 data showed that urban- rural gap is widening at country level.

Idrees and Ahmad (2010) with the help of Household Integrated Economic Survey(HIES) from 1990-91 to 2004-5 found inequality in Pakistan rural and urban areas based on consumption. Asad and Ahmad (2011) showed upward trend from 1990 to 1997 in inequality.

Cheema (2012) found relationship between income inequality, poverty and growth. Cheema (2012) argued that growth of economy helps to enhance income of population but not necessary to reduce poverty, it may increase inequality and further aggravates the situation, poor become more poorer and rich become more rich.

Husain and Kennedy (1999), Rajkumar and Swaroop (2008) observed that good governance required for effective allocation of resources, to bring comparative advantage, to increase productivity, to make market more competitive and most importantly to distribute the resources equitably in any society.

Kaufmann, Kraay, and Zoido-Lobatón (1999); Kaufmann and Kraay (2002); Kaufmann, Kraay, and Mastruzzi (2006) found a large causal effect of good governance on strong institutions, growth and development.

Pasha (2000) concentrated on the concept of good economic governance and proposed that there are nine elements related to good economic governance. Haq, Zia, and Arif (2006) worked based on Kaufman governance indicators and showed poor political governance is very clear from the fact that Pakistan has lowest tax to GDP ratio. Pasha (2000); Haq et al. (2006); Grindle (2004) observed that good economic policy is essential for the growth in Pakistan. Osborne (2003) ranked Pakistan as 41 out of 58 countries indicating bad governance impact.

Human Development in South Asia (1999) observed governance issue in Pakistan. Ismail, Rizvi, and Mahmood (2000) observed that Pakistan faces issues in governance specifically due to strong link among various elites who have to become more powerful and get advantage up to maximum extent. Anwar (2009) observed that in Pakistan continuing poverty is due to inequality in terms of income distribution among various groups of people. Anwar (2009) further found that poor people and middle class lost their consumption while rich people gained in consumption which makes it clear that gap between poor and rich is widening in Pakistan.

Income inequality is calculated by Anwar (2009) based on consumption expenditure with the support of Pakistan Integrated Household Survey (PIHS) and Pakistan Social and Living Standard Measurement Survey (PSLSM) during the period of 2001 and 2005. Overall income inequality is 27.52 in 2001-02 which increases to 29.76. In 2001 ratio of highest to lowest was 5.5 which increases in 2004-05 to 6.24. Rural area Gini 
coefficient is 23.67 in 2001-02 which increases to 25.19 in 2004-05 and urban areas Gini coefficient shifted from 32.27 to 33.88 . Income inequality of Pakistan rises which supports our view and previous literature (Gradstein, 2007) that in those countries where governance is poor, income inequality is an issue.

Another work on consumption inequality covered by Asad and Ahmad (2011) shows that there is overall rising trend in consumption inequality. Urban area consumption inequality rises from 0.302 to 0.320 , nonetheless rural areas does not show any major change and remain at 0.252 levels in 2004-05 as compared to 0.254 in 1990-91. Asad and Ahmad (2011) argued that income inequality in rural areas not shifted due to foreign remittances from labor class.

Cheema and Sial (2010) computed Gini coefficient of income inequality in Pakistan from 1992-93 to 2005-06 which shows that overall income inequality rises in Pakistan. In 1992-93 inequality is 0.2685 which rises to 0.30 in $2005-06$. Rural inequality is 0.2388 in 1992-93 which shifted to 0.2438 in 2005-06 and in urban areas increases from 0.3170 to 0.3473 .

Ortiz and Cummins (2011) worked with the help of WDI (2011), quintile information extracted from UNU-WIDER(2008) and European Commission (2011) and Gini Index used prepared by Solt (2009) and observed that in Pakistan overall average income inequality decreases from 32.6 to 30.8 during the period of 1990 to 2005 . On the other hand, it showed that poorest 20 percent(Q1) of population's inequality rose from 8.1 to 9.1 while richest 20 percent (Q5) decreases from 41.7 to 40.5 .

\subsection{International Governance Indicators and Pakistan Ranking}

Worldwide Governance Indicators (WGI) developed by World Bank. From 1996 to 2011 there is not a single year when Pakistan's any governance indicator moved from negative to positive. There is a consistent negative value coming for all governance indicators. Political Stability and Absence of Violence shows worst position as compared to other indicators.

Another index which is prepared by Fraser Institute in favor of economic freedom and measures policies and institutions followed by country is Economic Freedom of the World. This index covers five broad areas.

First, we compare Pakistan's ranking with other South Asian countries as given in Economic Freedom Report of the World. Pakistan ranked 111 out of 144 countries ranking. Pakistan is in the last quarter of ranking and fourth in South Asian countries with similar score in ranking with India. Ranking positions highlight the fact that other countries in South Asia are better in above stated five main components as compared to Pakistan.

The first component shows Pakistan ranking at 4 which indicates that country heavily relies on political decisions rather than market forces. Implementation of legal system, protection of property rights are very important for effective and efficient operation of markets and to develop confidence of investors that their contracts will be enforced 
and their property rights will be protected. Pakistan ranking at 117 shows poor performance in this area and highlights the issues in judicial system and implementation of legal system which is available in books of laws but not practically implemented by government.

When we compare HDI ranking of neighboring countries and other South Asian countries, Pakistan is ranked lower than Sri Lanka and India. When we compare South Asian region with other regions of the world, only one region scored below South Asian region and that is Sub-Saharan Africa. South Asian region scored just above SubSaharan region and Pakistan is very close in ranking with low human development Sub-Saharan African countries.

\section{RESEARCH METHODOLOGY}

\subsection{Sample Size and Sampling methodology}

To measure governance, we take six governance indicators score as proposed by Kaufmann and Kraay (2008) from $\neg$ WWGI for the year 2000. Various researchers used World Bank Governance Indicators, World Economic Forum, Transparency International and many other indexes to work on various segments of governance and economic and social issues like (Anderson \& Marcouiller, 2002; Breton, 2004; Brunetti \& Weder, 1995; De Groot, Linders, Rietveld \& Subramanian, 2004; Easterly \& Levine, 2003; Rigobon \& Rodrik, 2005; Treisman, 2000).

Hence following the above researchers, we used Worldwide Governance Indicators to understand governance issue and its relationship with wealth concentration. We used 156 counties data to calculate correlation between wealth Gini and governance indicators in Table3.1(a)

\subsection{Statistical analysis and Technique}

The statistical analysis is comprises of OLS estimation and Correlation analysis. The conceptual based regression equations are predicted via OLS estimations. The basic assumptions for OLS estimations have already been tested before the estimation.

\subsection{Empirical Results of the Study}

As noted in the introduction, this paper contribution is to investigate the relation between governance of a country and its impact on income inequality. We empirically tested by developing methodology that wealth concentration and poor governance leads to inequality. We expect negative relation between these two variables. To test this empirically, we take world wealth concentration Gini as available in (Davies, Sandström, Shorrocks \& Wolff, 2011) paper for 229 countries. We used 156 counties data to calculate correlation between wealth Gini and governance indicators in Table3.1 (a)

Table 3.1(a) shows the result of correlation among governance indicators and wealth inequality which is significant at $1 \%$ and $5 \%$ except voice which is significant at $10 \%$. All governance indicators have significant negative relation as per researcher expectation; hence researcher concludes that when a state has bad governance, wealth inequality is 
on higher side. Further we estimate wealth concentration Gini on average of six governance indicators.

Table 3.2(a) reports the basic model summary on how wealth concentration affects governance. The dependent variable is governance and independent variable is wealth concentration Gini. Independent variable has negative effect on governance as shown in Table 3.2(a). This result suggests that wealth concentration has negative and significant effect on governance of a state.

From the above result it is evident that wealth inequality has governance issue. When we take Pakistan as a case, situation is worse because all governance indicators of Pakistan are on negative side. Wealth inequality is much more in Pakistan as compared to data presented by government authorities because wealth data in Pakistan in terms of Household Balance Sheet does not show real picture. Those who accumulate wealth discourage policies that revealed this wealth. They concealed this information from government agencies, hence successfully reduce their wealth.

We collected Corruption perception index data for the year 2011 and World Bank's Governance Index of 2011. First of all we removed those countries which were available in World Bank's Governance Index but not covered by Transparency International Index and finally reached to 182 observations. As per theoretical understanding, there should be negative relation between corruption perception index and governance indicators. This is based on this perception that poor governance leads to higher corruption in society.

Our correlation result confirms this understanding and we find significant negative relation between Corruption Perception Index of TI and World Bank's Governance Index as shown in Table 3.1(b)

We observed that when overall country governance is fragile then it is almost difficult for any country to show progress in macroeconomic, trade and other rules and regulation areas. To explore association among various governance indicators and economic freedom index, we calculate correlation by taking 2011 World Governance Indicators and World Economic Freedom Report Index ranking and find very strong positive correlation as shown in Table 3.1(c).

Each variable of governance indicators is positively significant with World Economic Freedom ranking that shows that better governance reflects better performance in political, legal, macroeconomic, trade and regulations areas hence strengthen overall business, social and political environment in any country. This further support our understanding that governance of a country plays significant role in the solution of various economic and social issues.

As it has been discussed by Perotti (1996), Aghion, Caroli, and Garcia-Penalosa (1999);

Davies, Shorrocks, Sandstrom,and Wolff (2007) and Davies and Shorrocks (2005) in various papers that wealth inequality data for many countries are not available, so 
Governance Issues in Pakistan and their Impact on Income Inequality

researchers generally use income inequality as proxy for wealth inequality. We gathered data for income inequality from World Bank and wealth inequality Gini coefficient data as provided by (Davies, Sandström, Shorrocks \& Wolff, 2011). Finally data is available for 130 countries. Data of income inequality Gini is not available for all countries in 2011, so we selected closest year for which income Gini for a country is available and relate it with wealth Gini. Figure 3.1 shows that wealth inequality is on higher side at all level of income inequality as well as showing same trend as income inequality presenting. We find correlation between income inequality and wealth inequality as shown in Table 3.3 which confirms previous researchers' findings that there is strong positive correlation between income inequality and wealth inequality. Similar result was found by (Ortiz, I., \& Cummins, M. 2011).

There are various researchers who did not directly take Worldwide Governance Indicators to measure governance but took various other variables to measure governance and showed association in governance and various economic and social development outcomes like (Rajkumar \& Swaroop 2008; Bulte, Damania, \& Deacon, 2005); Holmberg, Rothstein, \& Nasiritousi (2009). Following these researchers, we use income inequality and WWGI to understand relationship between governance and income inequality. We earlier suggested that bad governance negatively impact on income inequality in a country. We take data of governance indicators from World Bank's The Worldwide Governance Indicators of 2011 which covers 215 countries and Gini coefficient of income inequality for 213 countries. We are able to gather data for 156 countries for which both governance indicators and income inequality Gini coefficient are available. Table 3.1(d) exhibits correlations between income inequality (Gini coefficient) and governance indicators. Table 3.1(d) shows negative correlation between governance indicators and income inequality as per our understanding. The result shows that governance mechanism has association with income inequality in a society. All correlation coefficients have negative sign indicating that inequality rises when governance is poor. Only Political Stability is not significant while Absence of Violence indicator is significant at $10 \%$. Nevertheless both variables supported theoretical understanding of negative association with governance indicators. Thomas (2010) argued that variable which are used to show relationship should be consistent with the theoretical prediction about that relationship.

Governance has impact on income inequality and where governance of a state improves, helps to reduce inequality as also observed by Gradstein (2007). Various evidences in this regard obtained by (Persson \& Tabellini, 1991; Alesina \& Rodrik, 1994) from cross countries research and concluded that inequality is harmful and causes of various adverse economic and social outcomes and reduces growth.

Now we regress income inequality on governance indicators and expect negative relation.

Table 3.2(b) reports basic model summary on how governance affects income inequality. The dependent variable is income inequality and independent variable is governance. Independent variable has negative effect on income inequality. This result helps us to understand that bad governance has negative and significant effect on income inequality 
of a state.

\section{CONCLUSION AND RECOMMENDATIONS}

Governance is an organizing concept which applies to all social sciences. Governance was popularized by international institutions led by World Bank has key role. Various other institutions took part in governance measurement and improvement from different points of view including Transparency International, Economic Freedom Report, World Economic Forum, etc. A growing literature stresses and supports that governance is important and play a vital role in economic development and prosperity of a country. Pakistan faces weak political governance and considered a fragile state due to unstable political government. Various coalitions have been formed to rule the country but all groups are interested in their own benefits, consequently emerged as unstable coalitions. Plenty of examples are present in Pakistan which indicate governance failure, like energy crisis, low and stagnant tax to GDP ratio, high debt burden, high incidence of tax evasion, regressive tax system, high losses of public sector enterprises, burden of subsidies, high corruption and misappropriation in development fund and posting of inefficient people in public sector enterprises. Corruption and patronage is present in all government offices from lower to top level. Poor performance, delayed cases and corruption in the lower courts have not been improved. Fiscal deficit is on the higher side which puts pressure on the incumbent government to borrow more funds from internal and external sources.

Poor governance is reflected through government inability to generate sufficient revenue to cover expenditures resulting in high budget deficit. Government imposes indirect taxes on public rather than putting emphasis on direct taxation which shifts burden from rich class to poor people. Huge corruption in Pakistan Railway, massive financial fraud in the National Assembly Employees Cooperative Housing Society and fake degree issue of parliamentarians shows lack of accountability of politicians. Allotment of urban land by KDA, CDA and LDA to influential people at highly subsidized rates, conversion of agricultural land into industrial land and then sold at high margin of profit are few examples of rent seeking activities of politicians.

Above discussion leads us to this conclusion that governance of the country is poor. Political misgovernance has had a damaging impact on economy of Pakistan and creating inequality. This paper examined the impact of governance of country on income and wealth concentration.

Pakistan presents overall weak governance in every walk of life which is indicated by all international governance measurement indicators developed by World Bank, Fraser Institute, World Economic Forum, Fragile State Index Ranking, United Nations Human Development, Transparency International etc.

It is suggested that improvement in governance is not a single day task, it cannot be achieved at once and it is not related to any one department or one institution. It's a process that will establish equality, effective management of economic resources; 
To achieve good governance strong political will and commitment will be needed. International financial institution, UNDP is working and giving guidelines to improve governance but government should not only consider their recommendations, we should also work and understand the local ground realities and environment as well as institutional capacity. Civil society, impartial media, NGOs participation is necessary. However it is important to understand that as times passes, situation will aggravate and more things would need to be done. For example in the case of Pakistan, there is, at present no work in the area of land reform. Wealth tax net should be broadened to bring more wealthy people within tax ambit.

\section{ACKNOWLEDGEMENT}

First of all with a profound gratitude, we are thankful to Almighty Allah forgiving us success, knowledge and understanding without which we would not been capable of completing this research paper.

We are also profoundly grateful to all our family members whose endurance and understanding have played a significant role in our success by sacrificing the important family time and supporting us all over the research work.

We are finally thankful to the editor, reviewers and IBT specially who provided us with the opportunity to publish our research paper in this esteemed journal.

\section{REFERENCE}

Adams, R. H., \& Alderman, H. (1992). Sources of income inequality in rural Pakistan: a decomposition analysis. Oxford Bulletin of Economics and Statistics, 54(4), 591-608.

Aghion, P., Caroli, E., \& Garcia-Penalosa, C. (1999). Inequality and economic growth: the perspective of the new growth theories. Journal of Economic literature, 37(4), 1615-1660.

Aidt, T. S. (2003). Economic analysis of corruption: a survey*. The Economic Journal, 113(491), F632-F652.

Akhtar, S. (2008). Trends in Regional Inequalities in Pakistan: Evidence Since 1998. Lahore Journal of Economics, 13(Special Edition), 205-220.

Akram, Z., Wajid, S., Mahmood, T., \&Sarwar, S. (2011). Impact of poor governance and income inequality of poverty in Pakistan. Far East Journal of Psychology and Business, 4(4), 43-55.

Alesina, A., \&Perotti, R. (1996).Income distribution, political instability, and investment. European Economic Review, 40(6), 1203-1228.

Alesina, A., \&Rodrik, D. (1994).Distributive politics and economic growth. The Quarterly Journal of Economics, 109(2), 465-490.

Alesina, A., Özler, S., Roubini, N., \&Swagel, P. (1996).Political instability and economic growth. Journal of Economic growth, 1(2), 189-211.

Anderson, J. E., \&Marcouiller, D. (2002). Insecurity and the pattern of trade: an empirical investigation. Review of Economics and statistics, 84(2), 342-352.

Anwar, T. (2009). Measuring Inequality of Consumption and Opportunities In Pakistan: 2001-02 and 2004-05. Pakistan Economic and Social Review, 157-181. 
Asad, M. A., \& Ahmad, M. (2011). Growth and consumption inequality in Pakistan. Pakistan Economic and Social Review, 69-89.

Barro, R. J. (1991). Economic growth in a cross section of countries. The quarterly journal of economics, 106(2), 407-443.

Benabou, R. (1996). Inequality and growth. In NBER Macroeconomics Annual 1996, Volume 11 (pp. 11-92). MIT Press

Breton, T. R. (2004). Can institutions or education explain world poverty? An augmented Solow model provides some insights. The Journal of Socio-Economics, 33(1), 45-69.

Brunetti, A., \&Weder, B. (1998). Investment and institutional uncertainty: a comparative study of different uncertainty measures. WeltwirtschaftlichesArchiv, 134(3), 513-533.

Brunetti, Y., \&Weder, B. (1995). Political sources of growth: a critical note on measurement. Public Choice, 82(1-2), 125-134.

Bulte, E. H., Damania, R., \& Deacon, R. T. (2005).Resource intensity, institutions, and development. World Development, 33(7), 1029-1044.

Cheema, A. R. (2012). Poverty, Income Inequality, and Growth in Pakistan: A Pooled Regression Analysis Ahmed RazaCheema and Maqbool H. Sial.Lahore Journal of Economics, 17(2), 137-157.

Cheema, A. R., \& Sial, M. H. (2010). Estimating the contributions of growth and redistribution to changes in poverty in Pakistan. Pakistan Economic and Social Review, 279-306.

Davies, J. B., \&Shorrocks, A. (2005, January).Wealth holdings in developing and transition countries.In Luxembourg Wealth Study Conference.January(Vol. 27).

Davies, J. B., Sandström, S., Shorrocks, A., \& Wolff, E. N. (2007). Estimating the level and distribution of global household wealth (No. 2007/77).Research Paper, UNU-WIDER, United Nations University (UNU).

Davies, J. B., Sandström, S., Shorrocks, A., \& Wolff, E. N. (2011).The Level and Distribution of Global Household Wealth*. The Economic Journal, 121(551), 223-254.

De Groot, H. L., Linders, G. J., Rietveld, P., \& Subramanian, U. (2004).The institutional determinants of bilateral trade patterns. Kyklos, 57(1), 103-123.

De Kruijk, H., \& Kemal, A. R. (1987).Sources of Income Inequality in Pakistan [with Comments]. The Pakistan Development Review, 26(4), 659-672.

De Kruijk, H., Van Leeuwen, M., \& Kemal, A. R. (1985).Changes in Poverty and Income Inequality in Pakistan during the 1970s [with Comments]. The Pakistan Development Review, 24(3/4), 407-422.

Easterly, W., \& Levine, R. (2003). Tropics, germs, and crops: how endowments influence economic development. Journal of monetary economics, 50(1), 3-39.

Glaeser, E., Scheinkman, J., \&Shleifer, A. (2003).The injustice of inequality.Journal of Monetary Economics, 50(1), 199-222.

Gradstein, M. (2007).Inequality, democracy and the protection of property rights*. The Economic Journal, 117(516), 252-269.

Grindle, M. S. (2004). Good enough governance: poverty reduction and reform in developing countries. Governance, 17(4), 525-548.

Haq, R., Zia, U., \& Arif, G. M. (2006). Governance and Pro-poor Growth: Evidence from Pakistan [with Comments]. The Pakistan Development Review, 761-776. 
Holmberg, S., Rothstein, B., \&Nasiritousi, N. (2009). Quality of government: what you get. Annual Review of Political Science, 12, 135-161.

Human Development in South Asia (1999). The MahbubulHaq Human Development Centre. Oxford University Press, pp: 1-208.

Husain, I., \& Kennedy, C. H. (1999). Institutions of Restraint: The Missing Element in Pakistan's Governance [with Comments]. The Pakistan Development Review, 38(4), 511-536.

Hyden, G. Court, J.(2002). Governance and development. Idress, M., \& Ahmad, E (2010). Measurement and Decomposition of Consumption Inequality in Pakistan. The Lahore Journal of Economics, 99-112.

Ismail, Z. H., Rizvi, S., \&Mahmood, A. (2000). Governance, Decentralisation, and Poverty: The Case of Pakistan [with Comments]. The Pakistan Development Review, 1013-1030.

Kaufmann, D., \&Kraay, A. (2002).Growth without governance. World Bank Policy Research Working Paper, (2928).

Kaufmann, D., \&Kraay, A. P. Zoido-Lobatón (1999)“Governance matters”.Policy Research Working Paper, 2196.

Kaufmann, D., Hellman, J., Jones, G., \&Schankerman, M. (2000). Measuring governance, corruption, and state capture: How firms and bureaucrats shape the business environment in transition economies. World Bank Policy Research Working Paper, (2312).

Kaufmann, D., Kraay, A., \&Mastruzzi, M. (2006).Measuring governance using crosscountry perceptions data. International handbook on the economics of corruption, 52.

Keefer, P. E. (2004). A review of the political economy of governance: from property rights to voice (Vol. 3315). World Bank-free PDF.

Kemal, A. R. (2006). Income Inequalities in Pakistan and a Strategy to Reduce Income Inequalities. Background Paper for PRSP-II, PRSP Secretariat, Government of Pakistan.

Khandker, R. H. (1973). Distribution of income and wealth in Pakistan. Pakistan Economic and Social Review, 1-39.

Mauro, P. (1995). Corruption and growth. The quarterly journal of economics,110(3), 681-712.

Ortiz, I., \& Cummins, M. (2011). Global Inequality: Beyond the bottom billion-A rapid review of income distribution in 141 countries.

Osborne, E. (2003). Measuring bad governance. Cato J., 23, 403. Pakistan faces lowgrowth equilibrium. ( 2013, October 10). Dawn.com. Retrieved from http://www.dawn.com/news/1048662/pakistan-faces-low-growth-equilibrium Pakistan ranked 124th amid 144 economies. (2012, September 05). The News. http://www.thenews.com.pk/article-66430-Pakistan-ranked-124th-amid-144economies

Pasha, H. A. (2000). Elements of Good Economic Governance.Social Policy and Development Centre.

Perotti, R. (1996). Growth, income distribution, and democracy: what the data say. Journal of Economic growth, 1(2), 149-187.

Persson, T., \&Tabellini, G. (1991). Is inequality harmful for growth? Theory and evidence (No. w3599).National Bureau of Economic Research. 
Rajkumar, A. S., \&Swaroop, V. (2008). Public spending and outcomes: Does governance matter?. Journal of development economics, 86(1), 96-111. Rigobon, R., \&Rodrik, D. (2005). Rule of law, democracy, openness, and income. Economics of Transition, 13(3), 533-564.

Shen, C., \& Williamson, J. B. (2005).Corruption, Democracy, Economic Freedom, and State Strength A Cross-national Analysis. International Journal of Comparative Sociology, 46(4), 327-345.

Thomas, M. A. (2010). What Do the Worldwide Governance Indicators Measure\&quest. European Journal of Development Research, 22(1), 31-54.

Treisman, D. (2000). The causes of corruption: a cross-national study. Journal of public economics, 76(3), 399-457.

Venieris, Y. P., \& Gupta, D. K. (1986). Income distribution and sociopolitical instability as determinants of savings: a cross-sectional model. The Journal of Political Economy, 873-883.

World Bank (2010). Doing business in Pakistan : comparing regulation in 13 cities and with 183 economies. Doing business subnational, Washington D.C., The Worldbank. http://documents.worldbank.org/curated/en/2010/01/17197387/doingbusiness-pakistan-comparing-regulation-13-cities-183-economies. 


\section{APPENDIX}

Table 3.1 (a-d) Correlation results between Inequality Gini and Governance Indicators

\begin{tabular}{|l|c|r|r|r|r|c|}
\hline & Voice & Political & Govt. & Regulatory & Rule & Corruption \\
\hline a & $-.143^{* * *}$ & $-.167^{* *}$ & $-.226^{*}$ & $-.162^{* *}$ & $-.203^{*}$ & $-.188^{* *}$ \\
\hline b & $-.758^{*}$ & $-.778^{*}$ & $-.923^{*}$ & $-.854^{*}$ & $-.938^{*}$ & $-.943^{*}$ \\
& & & & & & \\
\hline c & $0.593^{*}$ & $0.632^{*}$ & $0.766^{*}$ & $0.844^{*}$ & $0.753^{*}$ & $0.717^{*}$ \\
\hline d & $-.136^{* * *}$ & -.058 & $-.284^{*}$ & $-.274^{*}$ & $-.282^{*}$ & $-.202^{*}$ \\
\hline
\end{tabular}

*significant at $1 \%$

**significant at $5 \%$

*** Significant at $10 \%$

Table No.3.2 (a-b) Regression Results of Wealth Concentration, Income Inequality and Governance Indicators.

\begin{tabular}{|l|c|c|c|c|c|l|}
\hline & & & & & W. Gini & Sig. \\
& $\mathrm{R}$ & R Square & $\mathrm{F}$ & Sig. & & \\
\hline $\mathrm{a}$ & .223 & .050 & 8.093 & .005 & -0.022 & .005 \\
\hline $\mathrm{b}$ & .223 & .050 & 8.093 & .005 & -2.316 & .005 \\
\hline
\end{tabular}

Table 3.3 Correlation between Wealth Inequality and Income Inequality

\begin{tabular}{|c|rc|}
\hline & \multicolumn{2}{|c|}{ Income Gini } \\
\hline Wealth Gini Pearson Correlation & & .612 \\
Sig. & .000 \\
\hline
\end{tabular}




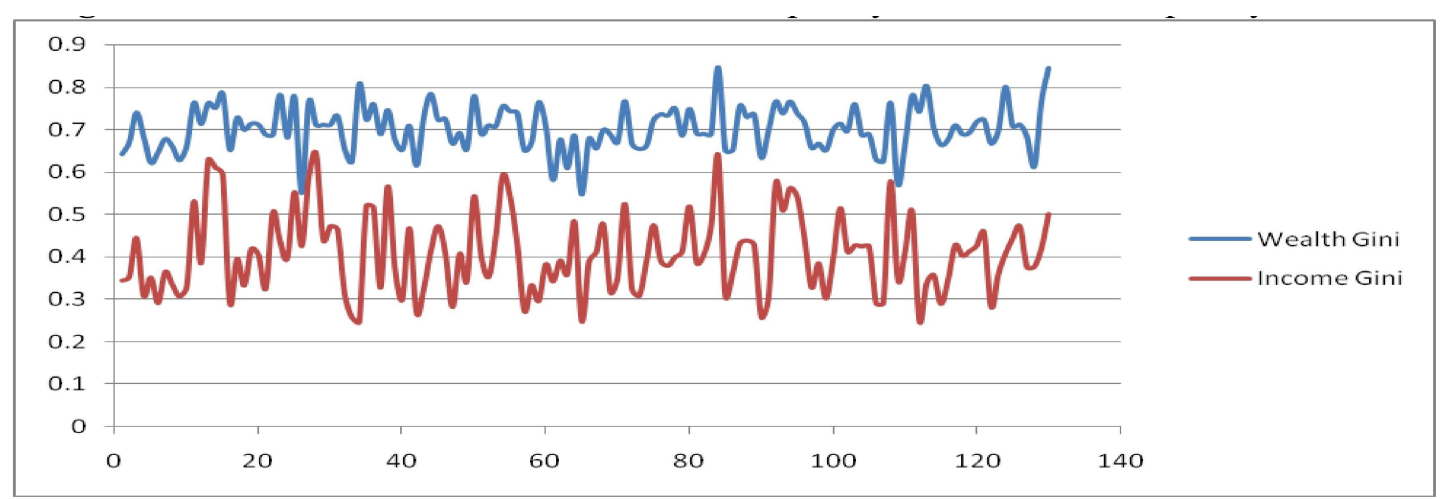

